\title{
Cybersemiotics and the Reasoning Powers of the Universe Philosophy of Information in a Semiotic-Systemic Transdisciplinary Approach
} Brier, Søren

\section{Published in:}

Green Letters

DOI:

10.1080/14688417.2015.1070684

Publication date:

2015

Citation for published version (APA):

Brier, S. (2015). Cybersemiotics and the Reasoning Powers of the Universe: Philosophy of Information in a Semiotic-Systemic Transdisciplinary Approach. Green Letters, 19(3), 280-292.

https://doi.org/10.1080/14688417.2015.1070684

Link to publication in CBS Research Portal

\section{General rights}

Copyright and moral rights for the publications made accessible in the public portal are retained by the authors and/or other copyright owners and it is a condition of accessing publications that users recognise and abide by the legal requirements associated with these rights.

Take down policy

If you believe that this document breaches copyright please contact us (research.lib@cbs.dk) providing details, and we will remove access to the work immediately and investigate your claim. 


\title{
Cybersemiotics and the Reasoning Powers of the Universe: Philosophy of Information in a Semiotic- Systemic Transdisciplinary Approach
}

\author{
Søren Brier \\ Journal article (Post print version)
}

This is an Accepted Manuscript of an article published by Taylor \& Francis Group in Green Letter: Studies in Ecocriticism on 16 Sep 2015, available online: http://www.tandfonline.com/doi/abs/10.1080/14688417.2015.1070684

Uploaded to Research@CBS: September 2015

Available at: http://research.cbs.dk/da/publications/cybersemiotics-and-thereasoning-powers-of-the-universe\%28650abb98-d36d-4230-bf08ca81dc8154cf\%29.html 
Cybersemiotics and the Reasoning Powers of the Universe: Philosophy of information in a semiotic-systemic transdisciplinary Approach

\author{
Søren Brier, Copenhagen Business School, Department of International Business \\ Communication \\ sb.ibc@cbs.dk
}

\title{
Abstract
}

To follow the transdisciplinary ambition in much information science and philosophy leading to cognitive science we need to include a phenomenological and hermeneutical ground in order to encompass a theory of interpretative meaning and signification to achieve a transdisciplinary theory of knowing and communication. This is also true if we start in cybernetics and system theory that also have transdisciplinary aspirations for instance in Batesons ecological concept of information as a difference that makes a difference and in Luhmann's triple autopoietic communication based system theory. Charles Sanders Peirce's pragmaticist semiotics integrates logic and information in interpretative semiotics. But although Peirce's information theory is built on meaningful signs and he connects information to the growth of symbols, his information theory is empirically based in a realistic worldview, which in the development to modern biosemiotics include all living systems.

Keywords: transdisciplinarity, Peirce's information concept, cybernetics, systems and semiotic, Luhmann's communication theory, realistic worldview, phenomenology, hermeneutics.

\section{Introduction to the problem}

The founder of semiotics C.S.Peirce ${ }^{1}$ shows that the starting point for the concept of information must be not only mathematical and logical but also phenomenological, but still within a realistic - but not mechanistic - worldview connected to an empiricist and fallibilist view of knowledge. It is my view that C.S. Peirce - by at the same time contributing to the development of modern logic and science as well as inventing a transdisciplinary semiotics that embraced phenomenology - also tried to heal the split between science and phenomenology.

\footnotetext{
${ }^{1}$ We are using the classical Peirce scholar reference system, where CP: refers to Peirce, C.S. (1994a [1866-1913] and 1994b [1931-5]): The Collected Papers of Charles Sanders Peirce. W: Peirce, C.S. (1982-2014 ). The Writings of Charles S. Peirce: A Chronological Edition Volumes 1-6. References take the form CP or W n. $\mathrm{m}$. where $\mathrm{n}$ and $\mathrm{m}$ indicate volume and page number respectively. EP: Peirce, C.S. (1998). The Essential Peirce. Volume 1 and 2. Eds. Peirce edition Project. Bloomington I.N.: Indiana University Press.
} 
In a philosophy of science we have great problems in inserting the subjective first person experiential aspect of reality in our view of information. But philosophy - and that goes for information philosophy too - aims primarily at developing the kind of knowledge that gives unity and system to the whole body of human, social and natural sciences. This is done through a critical examination of the grounds of our convictions, prejudices, and beliefs and the methods we use in the sciences, which we think could benefit by being further developed on a Peircean pragmaticist framework.

Living organisms can be described from a natural scientific as well as a phenomenologicalhermeneutical humanistic type of knowledge system. Organisms' genes and physiology, as well as their experiences, learning capability and social role, have causal influence on their behavior. Thus, the general study of embodied life falls between the traditional organizations of subject areas grouped in Snow's two cultures of sciences and humanities. A central problem is that this 'two cultures' view lacks a common epistemological and ontological framework, unless you are into hard dualism. The two cultures view was based on a knowledge organisation founded before evolutionary theory was broadly, i.e. trans-disciplinarily, accepted. But how can biology be an experiential as well as an empirical Wissenschaft ${ }^{2}$ when animals have no human language games to convey their first person experience, but only instinctual sign games? Actually in the light of behaviourism and ethology, and even in much cognitive science today, it is fashionable to deny animals any experiential capability that can have any causal effect on their behaviour. One reason for that is that the concept of experience and meaning does not exist in the vocabulary of the theoretical framework of natural sciences. This is a fact which Konrad Lorenz (1970-71) had to recognise when he worked hard over a period of 30 years to establish a theoretical framework for ethology. The development of biosemiotics over the last 50 years (Favareau 2010 , and see essay in this volume) is an attempt productively to solve this transdisciplinary problem.

\section{Building blocks of a transdisciplinary framework}

At the moment this is mainly done by combining the transdisciplinary frameworks of system science and cybernetics with Peircean semiotics and Jacob von Uexküll's work on functional cycles and Umwelten (Kull et.al. 2009). Practically, biosemiotics has had to make its own international scientific association with yearly conferences, and create its own journal and book-series with Springer. But the contemporary challenge of biosemiotics is now to develop new empirical methods and a new transdisciplinary framework for its interdisciplinary work in a better understanding of non-human organisms and human cultural phenomena. Such a new theoretical framework and experimental methods hold a promise, in particular, for medicine that needs to integrate biomedicine with psychosomatics and social medicine (for instance in dealing with placebo effects in a productive way). Biosemiotics usually wants to see itself as a complementary view to the molecular paradigm, not taking over its role as dominating understanding and socially accepted explanations of the living. But what then is the theoretical platform for such an endeavour if we do not accept logical empiricism and the reductionist and 'dataistic' unity of a science view (for instance in its modern pan-informational

\footnotetext{
${ }^{2}$ Wissenschaft is a more interdisciplinary concept than science if we do not want to call phenomenology a science.
} 
cognitive science form), and if we do not want to end up in a radical constructivist postmodernism giving up the realistic foundation for empirical work and truth as an ideal for Wissenschaft (Brier and Joslyn 2013)? If interdisciplinarity is going to compete with the long disciplinary traditions, and stop being 'a jack of all trades, but master of none', it has to develop deep interdisciplinary theoretical frameworks that make it possible for us to go beyond the pan-informational philosophy or what, these days, is also called the info-computational paradigm.

Peirce integrated his semiotics with a pure mathematical analysis of phenomenology through which he coined three 'new' basic categories: Firstness, Secondness and Thirdness (Esposito, 1980). He furthermore viewed logic, aesthetics and ethics as basic normative sciences necessarily connected with the metaphysics developed for any philosophy of cognition and communication. The normative sciences are those sciences driven by questions of value and purpose. Since facts do not simply speak for themselves, this means that researchers in these fields must be aware of the part (not necessarily negative) that their own values and purposes play in identifying the apparent drivers of phenomena. This, in turn, will tend to dictate what counts as scientific progress. As Peirce points out this is inevitably, in fact, a question of metaphysics, howsoever disguised as "common sense". Peirce's own view is that the 'logic' of the normative sciences is semiotic: i.e. science grows because it is in the nature of signs to grow. ${ }^{3}$ Peirce writes:

Philosophy has three grand divisions. The first is Phenomenology, which simply contemplates the Universal Phenomenon and discerns its ubiquitous elements, Firstness, Secondness, and Thirdness, together perhaps with other series of categories. The second grand division is Normative Science, which investigates the universal and necessary laws of the relation of Phenomena to Ends, that is, perhaps, to Truth, Right, and Beauty. The third grand division is Metaphysics, which endeavors to comprehend the Reality of Phenomena. Now Reality is an affair of Thirdness as Thirdness, that is, in its mediation between Secondness and Firstness..." (Peirce: CP 5.121)

This led him to develop the highly original view on logic that its core is the study of the essential nature of signs. Logic is semiotic. His triadic categorical theory was connected to a dynamic triadic semiotic web viewed as the dynamics of objective mind (Raposa 1989, 146). This sets him clearly apart from logical positivism and dialectical materialism, even though his three categories in many ways were close to Hegel's process logic dialectics of thesis, anti-thesis and synthesis and their further development in dialectical materialism. The important difference is Peirce's concept of Secondness or brute specific not immediately or completely explainable by law, like the grain of sand in our mouth when eating at the beach. Law cannot exhaustively explain why this specific grain of sand was to be here at that spot in that time.

\footnotetext{
${ }^{3}$ Readers looking for a general account of these matters may wish to consult the 'Scientific Progress' entry of the Stanford Encyclopedia of Philosophy at: http://plato.stanford.edu/entries/scientific-progress/
} 
We can see Peirce's semiotic pragmaticism as the synthesis of the phenomenological objective idealism of Hegel and Marx-Engels and Lenin's dialectical materialism through his theory of semiosis. Peirce's pragmaticism combines his theory of logic-as-semiotic with evolutionary theory. He thereby creates a philosophy different from Hegel's, and improving considerably on Schelling's, who was an important influence on his philosophy. Peirce's ontological foundation is semiotic rather than informational in that information is seen as an aspect of semiosis.

Frederik Stjernfelt (2014) points out that one of the most important lessons to take from Peirce's semiotics is its vast reorientation of the whole domain of sensation, perception, logic, reasoning, thought, language, images etc. towards the chain of reasoning as its uniting primitive phenomenon. The point of Peirce's semiotic philosophy of pragmaticism is that this development of reasoning may be formally described independently of the materials in which it may be implemented. This view implies that propositions are not primarily entities of language, nor do they presuppose any conscious 'propositional stance'. Rather, reasoning capacity is developed through evolution in nature. The evolution of consciousness and language should rather be seen as scaffolding, serving and increasing reasoning, which is one the most important overall selecting factors during evolution, Stjernfelt (2014) argues. Thus, language, images, perception etc. should be re-conceptualized for the roles they may play in the chain of propositions that construct the reasoning processes. Here is a quote that makes it clear how Peirce sees semio-logical processes permeating all levels of living systems:

The cognition of a rule is not necessarily conscious, but is of the nature of a habit, acquired or congenital. The cognition of a case is of the general nature of a sensation; that is to say, it is something which comes up into present consciousness. The cognition of a result is of the nature of a decision to act in a particular way on a given occasion. In point of fact, a syllogism in Barbara virtually takes place when we irritate the foot of a decapitated frog. The connection between the afferent and efferent nerve, whatever it may be, constitutes a nervous habit, a rule of action, which is the physiological analogue of the major premise. The disturbance of the ganglionic equilibrium, owing to the irritation, is the physiological form of that which, psychologically considered, is a sensation; and, logically considered, is the occurrence of a case. The explosion through the efferent nerve is the physiological form of that which psychologically is a volition, and logically the inference of a result. When we pass from the lowest to the highest forms of innervation, the physiological equivalents escape our observation; but, psychologically, we still have, first, habit--which in its highest form is understanding, and which corresponds to the major premise of Barbara; we have, second, feeling, or present consciousness, corresponding to the minor premise of Barbara; and we have, third, volition, corresponding to the conclusion of the same mode of syllogism. (CP 2.711).

Ontologically this means that evolution is neither completely random nor completely mechanical, but is a development of the reasoning powers of the universe. This is a move away from the 
reductionist pure physicalism into a broader philosophical framework that can encompass a transdisciplinary view of Wissenschaft, ${ }^{4}$ man and universe.

It is well-known that we do not see data (Popper 1959, 76). We see things, forms, classes, and behaviour. The concepts of our languages form our sense experiences and cognitions and what we consider meaningful and can perceive. On this basis, Bateson's (1973) definition of information 'as a difference that makes a difference' is still valid. Information is what one receives in reply to a question of living. I agree with Bateson (1973) and Maturana (1988a, 1988b) and Peirce (1994 [1866-1913]) that we must start our understanding of information with the process of knowing. Bateson's definition of information as a difference that makes a difference is very fruitful. His problem is that he nearly makes every cybernetic system a communicator and a knower, be it a homeostatic machine, an organism or an ecosystem or organization. The main achievement of Maturana and Varela's (1980, 1986) theory of autopoiesis is that they have conceptualised the basic limit of living and knowing, namely the autopoietic system, and shown that there is a basic connection between living and knowing! In Maturana's vision the autopoietic system is closed in its structure-dependent organization.

Once autopoietic reproduction begins, natural selection becomes possible, and survival knowledge - in the form of structural couplings' readiness to act in an orderly way on certain disturbances from the environment - begins to emerge and grow. These autopoietic structures that are connected to the ability to produce their own macromolecules create 'semantic closure'. Solutions to survival problems are kept as kinds of reaction potentials within the organism, some of them as molecular structures in the DNA-RNA-protein-synthesis processes. This is why Konrad Lorenz, in his development of ethology, was so keen on viewing instinct as the connection between motivation and fixed action patterns. This enables the system to perpetuate its autopoiesis from one instant to the next through generations of self-production as a full-bodied individual, and self-reproduction through the 'digital coding' in the DNA that is transferred and mixed in mating (Brier 2008a). Jesper Hoffmeyer and Claus Emmeche (1991) called these two forms of 'memory' (in DNA-RNA and in the flesh) codeduality. The analogue code is the actual living body as phenotype, and the digital code is the genotype of the genome. These two codes then interchange over time. One can say that discreteness and continuity are two irreducible complementary modes of thinking and also of existence. Thus autopoiesis and biosemiotics can fruitfully be integrated as autopoiesis gives a dynamic embodiment to semiotic interaction.

It is Peirce's view of the sign as a real and dynamical developing relational and reasoning process that makes him argue that there is nothing in thought or in sensation, which was not first in signs (Deely 2013, xxvii). Peirce's probably most famous definition of his new conception of signs is this:

\footnotetext{
${ }^{4}$ As the concept of science tends to be interpreted as natural or quantitative sciences I prefer the German word Wissenschaft as it - like the Danish videnskab - encompasses the social, the technical and the life sciences and the humanities as well.
} 
A sign, or Representamen, is a First which stands in such a genuine triadic relation to a Second, called its Object, as to be capable of determining a Third, called its Interpretant, to assume the same triadic relation to its Object in which it stands itself to the same Object. The triadic relation is genuine, that is its three members are bound together by it in a way that does not consist in any complexus of dyadic relations. That is the reason the Interpretant, or Third, cannot stand in a mere dyadic relation to the Object, but must stand in such a relation to it as the Representamen itself does. Nor can the triadic relation in which the third stands be merely similar to that in which the First stands, for this would make the relation of the Third to the First a degenerate Secondness merely. (C.P. 2-274).

This non-reducible triadic process relation - that is not primarily driven by any human subject's consciousness and therefore opens a foundation for a biosemiotics - is foundational to Peirce's pragmaticist philosophy. The Sign as an irreducible triad is a syllogism - although not of the familiar type found in Barbara (e.g. major premise: all men are mortal; minor premise: Socrates is a man; conclusion: Socrates is mortal). The major premise is the Representamen relation; the minor premise is the Object relation and the conclusion is the Interpretant. In other words, the major premise presents us with a sign, a piece of information about the world; the minor premise stands in the background of our thought as something that is in the world and which can arise on the basis of the major premise; the conclusion is akin to Bateson's formulation that only a 'difference that makes a difference', can become information. When it does and we need to use it again - we create a sign and therefore an awareness of the possible significance of the sign, so that our Interpretant will not only be a new thought, but will also result in a difference in our thinking (and behaving) more generally. We can see how this growth of the sign is important in science as well as art.

This is a dynamic transformative process. It's not just a mechanical conveyor belt because the information is acted upon and 'thought about' (interpreted) from input sensation to result. It is this conception of semiosis that makes inter- and transdisciplinarity possible. The best way to explain cosmogony and evolution is as a dynamic interaction between the three categories or universes as Peirce also calls them. None of the categories can be reduced to the other, but cosmogonically viewed they are derived from each other.

Since Firstness is a state of absolute possibility and radical indeterminacy as close to nothingness as possible, it is an absolute permissibility with no cause outside itself. From here Secondness emerges as one of many possibilities as difference, other, individuality, limit, force and will. Thirdness is the mediating habit-taking aspect of evolution that contributes to the creation of an emergent order theoretically somewhat differently modeled than Hegel's dialectical evolution and the dialectical materialism of Frederick Engels' (1873-1886) Dialectics of Nature as well. In contrast to Engels, Peirce's categories also have a phenomenological aspect. Peirce writes in 1907:

Firstly come "firstnesses," or positive internal characters of the subject in itself; secondly come "secondnesses," or brute actions of one subject or substance on another, regardless of law or of 
any third subject; thirdly comes "thirdnesses," or the mental or quasi-mental influence of one subject on another relatively to a third. (CP 5.469)

Thus if we start from the level of life in the beginning, 'knowledge' exists only as embodied in the inherent structural dynamics of the autopoietic entity. This would then, over a long time, result in the precise tri-nucleotide 'codes' which are used in DNA in all present organisms to determine specific amino acids to be produced by the ribosomes. But how exactly this is supposed to happen as a mechanical process, we do not know or can explain. But the general idea in Peircean biosemiotics is that, starting from random noise, the autopoietic functions of the cell make it possible to filtrate selectively for useful functionality. As such, researchers often say that this process gradually built knowledge of the world into the DNA sequence. But it cannot exist as knowledge per se. It only works if placed within a living cell with a full synthesis apparatus and a lot of other functional cycles and organelles surrounded by membranes.

The biological description is carried out on a purely chemical level, and even though we cannot produce a living cell in our test tubes today, it is believed that chemistry is all that there is to this development of agency. But the experiential agency is what we have been talking about so far as missing from traditional biological science: a distinct domain, of a self-referential autonomous state, which other regularities govern, and which cannot be reduced by the laws of the dual domains. A difference cannot become knowledge before it has been interpreted to be sufficiently meaningful and important that an observer/knower attaches a sign to it. Then it will make a difference. We have thousands of aspects of our reality, which we have not called anything and which therefore cannot easily be communicated or thought constructively about. Thus, what are transferred are sign-vehicles, not information. Signs have to be interpreted, and it has to happen on at least three levels. On the most basic level we have the basic coordination between the bodies as a dance of black boxes to allow for meaningful exchange. This goes on at the next level of instinctual sign plays of drive and emotionally based communication about meaningful things in life like mating, hunting, dominating, food seeking, territory etc. Based on these two levels a field of meaning is created, which, eventually, the sociocommunicative system can modulate to conscious linguistic meaning.

What Charles Sanders Peirce attempted was to change our worldview in order to encompass the world of science and logic with the world of meaning and communication through a triadic evolutionary pragmaticist theory of semiotics. This new but unfinished approach has attracted a multitude of researchers to make a consistent interpretation of his scattered work. See for instance Apel (1981), Boler (1963), Brent (1998) Colapietro (1989), Corrington, R. (1993), Deledalle (2000), Esposito (1980), Fisch (1986), Hookway (1992), Liszka (1996), Menand (2001), Savan (1987-1988) and Short (2007). 


\section{Triadic, evolutionary, realist pragmaticist semiotics}

The modern mechanistic ontology of science leaves us - as Jacques Monod (1972) already concluded in his analysis of a mechanical molecular biology - as 'Gypsies on the border of the universe'. Peirce would have agreed with Monod that the mechanical view is insufficient as philosophical transdisciplinary ontology and epistemology even in an evolutionary setting. Peirce writes:

the universe is not a mere mechanical result of the operation of blind law. The most obvious of all its characters cannot be so explained. It is the multitudinous facts of all experience that show us this; but that which has opened our eyes to these facts is the principle of fallibilism (CP 1.162).

We do not have absolute certain knowledge about the world based on absolute law, as many classical physicists tended to think. As Peirce begins his philosophy with observation and intersubjectivity, he denies that we have a special ability for introspection behind language and sign games. All of our knowledge is intersubjective, and the dichotomy of internal/external is not foundational, although is useful in other connections. Even our own self is a sort of sign that has developed through our whole life summing up and structuring all our experience into what Peirce, in his terminology, calls a symbol (Colapietro 1989). Peirce views the universe in another of his signs types, namely as a grand argument, which we, and in some ways all living systems, are trying to decipher.

This opens space for a much wider understanding of the complexity and meaningfulness of life and, not least, of human reality where one is concerned to build a philosophy encompassing both science and conjectures of meaning. Peirce was an architectonic systematic philosopher (Murphey1961) and can be compared to Aristotle in breadth, to Kant in modern transcendental thinking, to Hegel and Schelling in evolutionary vision, and to A.N. Whitehead (1978) in process philosophy. He connects all these aspects of philosophy into a new metaphysics including a new semiotic view of rationality. A reason to believe that Peirce's semiotics can move us out of some of our major contemporary conceptual obstacles (our metaphysics of modernity, one might say) is that he combines his view of semiotics and logic in an evolutionary pragmatic framework. He writes:

Logic will here be defined as formal semiotic. A definition of a sign will be given which no more refers to human thought than does the definition of a line as the place which a particle occupies, part by part, during a lapse of time. Namely, a sign is something, A, which brings something, B, its interpretant sign determined or created by it, into the same sort of correspondence with something, $\mathrm{C}$, its object, as that in which itself stands to C. It is from this definition, together with a definition of "formal", that I deduce mathematically the principles of logic.

(Peirce 1980, 20-21; 54) 


\section{Peirce's concept of information}

Peirce's concept of information generalizes Claude Shannon's (1949) to the degree that triadic sign relations generalize dyadic cause-effect notions of information transmission. But Peircean information is not substantially different inasmuch as it makes sense only in a context of prior uncertainty, the 'irritation of doubt' that drives inquiry, and its measure is based on the power of signs in a given sign relation to reduce the uncertainty of an interpreter about an object. In that view, signs bear information on account of their place in a specified sign relation, and it is a matter of secondary concern whether the sign is a picture, proposition, term, or something else entirely, like the state of a computer system. In what sense and to what degree might this 'information' be measured? Will the very notion of measuring this value not conflict with Peirce's contrite fallibilism, which holds that what a given term will come to mean to us is not something that can be decided in advance of scientific inquiry? Thus from a Peircean semiotic view scientific terms can hold a great deal of implicit information as well as the explicit information that scientists are working with at a given time. Therefore the information to be quantified is not that of what a given term will come to mean to us in some distant future, but rather that of what it means to us now or what we now conceive to be its practical bearing in general on conduct.

According to Peirce percepts are not, in themselves, objects of experience. Though the percept makes knowledge possible, it offers no information, as it does not contain any Thirdness in its immediateness, but is Secondness in its physical clash with the perceptual organ. But experience, understood as the knowing process imposed upon us in the course of living, is 'perfused' with Thirdness. Thirdness takes the form of generality and continuity within a fallible account of percepts. 'Meaning' must somehow be constructed by the receiver from the information produced by the interpretation of signs, within certain frames that reality imposes on us for survival. Peirce writes:

At any moment, we are in possession of certain information, that is, of cognitions which have been logically derived by induction and hypothesis from previous cognitions which are less general, less distinct, and of which we have a less lively consciousness. (Peirce CP 5.311, 1868).

Thus Peirce develops an information theory that starts with a physical event hitting the perceptual organs - i.e., Secondness - but he does not construct a probability-based theory of information as Claude Shannon or Norbert Wiener (1963) do.

Instead, Peirce develops a theory of human knowledge based on the logical quantities of extension and intension associated with the concept of symbol that is so vital for his semiotics. Thus Peirce defines his concept of information directly from his semiotics and its most important species of sign, namely, the symbol. For Peirce, plants and animals are constrained mainly, or nearly so, to iconic and indexical sign use. Instead of the probability-based theory of information developed by Shannon and by Wiener, Peirce develops a theory of human knowledge based on a kind of logical quantities within a field of dynamic meaning in that he introduces a new way of calculating the value of information 
conveyed by new propositions as a logical area composed of the informational breadth and depth of the symbol. He writes:

In a paper ... I endeavored to show that the three conceptions of reference to a ground, reference to a correlate, and references to an interpretant, are those of which logic must principally make use. I there also introduced the term "symbol," to include both concept and word. Logic treats of the reference of symbols in general to their objects. A symbol, in its reference to its object, has a triple reference: First, Its direct reference to its object, or the real things which it represents; Second, Its reference to its ground through its object, or the common characters of those objects; Third, Its reference to its interpretant through its object, or all the facts known about its object. What are thus referred to, so far as they are known, are: First, The informed breadth of the symbol; Second, The informed depth of the symbol; Third, The sum of synthetical propositions in which the symbol is subject or predicate, or the information concerning the symbol. By breadth and depth, without an adjective, I shall hereafter mean the informed breadth and depth. It is plain that the breadth and depth of a symbol, so far as they are not essential, measure the information concerning it, that is, the synthetical propositions of which it is subject or predicate. This follows directly from the definitions of breadth, depth, and information. ...we term the information the area, and write - Breadth X Depth = Area." (CP 2.418-419, 1868)

Thus symbols have extension, since they denote classes of objects, and intension, as the objects they denote must have certain characters in common. Peirce furthermore suggests measuring the amount of information that symbols acquire through their individual and cultural history of use. This idea is connected to what Peirce calls the 'growth of symbols' (Nöth 2012). The meaning of a symbol grows and develops through the years it is used in a culture. This growth is also augmented by the combination of terms in propositions as they then interact and change each other's meaning. Peirce writes:

No proposition is supposed to leave its terms as it finds them. ...; and there are three objects of symbols the connotative, denotative, informative; it follows that there will be three kinds of propositions, ... (Peirce W1:277).

When an adjective precedes a noun, the logical content of the noun is modified by the adjective. If the noun, 'information' is modified by the adjective 'physical', then the logical content of the abstract concept of information is modified by what the author understands the term 'physical' to mean. Thus, propositions are a further source of the growth of symbols and, in the sciences, synthetic propositions are a source of the acquisition of new knowledge.

Thus although Peirce's information theory is built on meaningful signs, he still has an information theory based in realism. One needs to have empirical reference in order to produce real information. Peirce writes: 
If there be anything that conveys information and yet has absolutely no relation nor reference to anything with which the person to whom it conveys the information has, when he comprehends that information, the slightest acquaintance, direct or indirect-and a very strange sort of information that would be-the vehicle of that sort of information is not, in this volume, called a Sign (CP 2.231, 1910).

In other words, analytical statements lack informativity. The more synthetic a proposition is (i.e., the greater the empirical reference that it has), the more informative it is. Quantity is a measure of the extension of a symbol. It refers to the fact that different symbols 'may denote more or fewer possible things; in this regard they are said to have extension.' (W1: 187). Thus, the extension of the symbol fish is larger than the one of shark since fish is applicable to more animals than shark. Quality, on the other hand, is dependent on the intension of a symbol, which is the number of characters attributed to a term. That is a logical quantity. This is a quantity very different from the probability theory underlying Shannon's and Wiener's (1963) objective information theories. In this sense, informational implication takes into account all available knowledge and not only the defining characters from which lexical definitions are made up. Peirce is saying that information is a process in which the symbol of shark, for instance, as a concept with a content that I know, is constantly undergoing development. When I see a documentary showing me many different species of sharks, that I did not know before, like reef sharks, then my symbol of sharks grows, because I have added information to my conception of the species shark by increasing the quantities of extension or intension of the symbol connected to it, which now include hammerheads within their scope. Peirce writes:

An ordinary proposition ingeniously contrives to convey novel information through signs whose significance depends entirely on the interpreter's familiarity with them; and this it does by means of a 'predicate,' i.e., a term explicitly indefinite in breadth, and defining its breadth by means of 'Subjects,' or terms whose breadths are somewhat definite, but whose informative depth (i.e., all the depth except an essential superficies) is indefinite, while conversely the depth of the Subjects is in a measure defined by the Predicate. (CP 4.543, 1905).

So it is not the lexical definition of 'shark' that carries the information, but all the other things I know about sharks' behaviour, size, colours, way of movement, prey, and how many of them we catch each day and eat in shark fin soup. Peirce underlines that 'the information of a term is the measure of its superfluous comprehension' (W1: 467), which is all the extraneous world knowledge I have about sharks, including if I have been bitten by one and where that was. In other words, information is all the knowledge 'outside' the lexical definitions! As Peirce holds a fallibilist view of science combined with a pragmaticist and realistic view of knowledge, he must conclude:

The cognitions which ... reach us ... are of two kinds, the true and the untrue, or cognitions whose objects are real and those whose objects are unreal. And what do we mean by the real? ... 
The real, then, is that which, sooner or later, information and reasoning would finally result in, and which is therefore independent of the vagaries of me and you (CP 5.311, 1868).

Thus Peirce produces a new transdisciplinary theory of information, connected to his semiotic theory of cognition and communication, which differs substantially from the usual conceptions. Peirce's theory combines the concepts of meaning and information within a framework of pragmatic realism established on a semiotic understanding of cognition and communication. Peirce's theory can be modernized by combining it with Luhmann's (1990 and 1995) communicative systems theory, which introduces autopoiesis at the level of biology, psychology, and social communication (Brier 2008a; 2011). Luhmann (1990) and Peirce both share the idea of form as the essential component in communication. Peirce writes:

[...] a Sign may be defined as a Medium for the communication of a Form. [...]. As a medium, the Sign is essentially in a triadic relation, to its Object which determines it, and to its Interpretant which it determines. [...]. That which is communicated from the Object through the Sign to the Interpretant is a Form; that is to say, it is nothing like an existent, but is a power, is the fact that something would happen under certain conditions. (MS: 793:1-3)

In Peirce's dynamic process semiotics, a form is something that is embodied in an object as a habit. Thus, form acts as a constraining factor on interpretative behaviour or what he calls a real possibility in the form of a 'would-be'. The form is embodied in the object as a sort of disposition to act (Nöth 2012). This is, by the way, probably also a better way of understanding the formal causal power of genes, not as deterministic and mechanical, but as dispositions to act in certain ways under certain environmental conditions. Laws are not absolute and mechanical but developing forms in the continuum of mind and matter and our ever developing fallibilist knowledge, of which symbols are an essential feature. Since mechanical determinism cannot explain the novelty of evolution and the emergence of the laws of nature, Peirce was aware that we needed an alternative ontology to the mechanistic one. As physicist Lee Smolin writes: "The Cosmological questions such as Why these laws? and Why the initial conditions? cannot be answered by a method that takes the laws and initial conditions as input." (Smolin 2014, 250). But this is what modern classical physics used to do and therefore Smolin's work here is quite revolutionary, and he is quite aware that the thought was foundational to Peirce's cosmogony and quotes him several places in the book.

One of the alternatives to mechanicism is to take the objective reality of irreversible time seriously, as Prigogine (1980; 1996; and with Stengers 1984) did, and now Smolin does, and to start with some of kind of non-mechanical objective chance as ontologically foundational. Peirce did that long before Prigogine and called it Tychism.

\section{Conclusion}

When scientific methods are applied to information, cognition, and communication, we are only left with codes, grammar, phonetics, programs, formal language, copy machines and adaptors; but then the 
analysis of meaningful relations is lost amidst all the formal technicalities. Contrary to the reductionist loss of meaning, cybersemiotics, following in the footsteps of Peirce, allows us theoretically to distinguish between the information the sender intended to be in the sign, the (possible) information in the sign itself, and the information the interpreter gets out of the sign. This gets us out of the trap of assuming that the information is a material 'thing' which is the same in all three. The knowledge in the sign must be interpreted for a full semiosis to happen, and for the receiver to acquire the information imparted (both intentionally and unintentionally) by his or her interlocutor. As such, it is central to any conception of knowledge and information.

In other words, we must accept that experience and meaning are just as real as matter. This does not mean that what physicists call the 'world' or 'reality' as such is imbued with meaning, but it does mean that reasoning is generated from its self-organizing processes. It means that their concept of 'world' and 'reality' is unable to reflexively encompass the embodied psychological and social foundation of knowledge. Peirce points out that self-reproduction and self-replication are not only characteristics of organisms and chromosomes, but also of symbols. Signs replicate through and in their tokens. Replicas of symbols in their acoustic or written form are indeed dead things (phenomena of Secondness), but symbols as genuine Thirdness are alive as self-replicative beings. It is within that wider reality of life connecting subjects in language and social actions to nature and technology that information is created.

Thus, in this transdisciplinary frame for interdisciplinarity, the sign process carrying the information content is viewed as transcending the division between nature and culture, between the natural sciences, the life sciences, the social sciences, and the humanities, and between phenomena that are exterior and those that are interior to human consciousness. We have moved from a mechanical idea of the 'Cosmos' to a self-organised evolutionary super-system. Though the combination of thermodynamics and the info-computational paradigms attempts to naturalize information computations to an 'Infos', but now we have started to move towards a 'Semios', that through a physio-semiotic cosmogony is encompassing and integrating the former understandings of matter and information in to a cybersemiotic view.

\section{References}

Apel, K-O. (1981), Charles S. Peirce: From Pragmatism to Pragmaticism, trans. J. M. Krois. Amherst: University of Massachusetts Press,

Bateson, G. (1973). Steps to an Ecology of Mind: collected essays in anthropology, psychiatry, evolution and epistemology, St. Albans: Paladin. Freedom, New Delhi/Thousand Oaks/London: Sage Publications.

Boler, J.F. (1963), Charles Peirce and Scholastic Realism: A study of Peirce's Relation to John Duns Scotus, Seattle: University of Washington Press. 
Brent, Joseph L. (1998), Charles Sanders Peirce: A Life, Revised and enlarged edition, 1998 Bloomington, IN: Indiana University Press.

Brier, S. (2008a. Cybersemiotics: Why Information is not enough, Toronto: University of Toronto Press, 2008.

Brier, S. (2009). Cybersemiotic Pragmaticism and Constructivism, Constructivist Foundations Vol. 5, No. 1, Pp. 19-38.

Brier, S. (2011). Ethology and the Sebeokian way from Zoosemiotics to Cyber(bio)semiotics", Deely, J., Kull, K. and Petrilli, S. (eds.), Semiotics Continues to Astonish: the Intellectual Heritage of Thomas Albert Sebeok, Chapter 4, pp.: 41-84, Paris and Den Haag: Mouton de Gruyter.

Brier, S. and Joslyn, C. (2013). "What Does It Take to Produce Interpretation? Informational, Peircean, and Code-Semiotic Views on Biosemiotics". Biosemiotics, Vol. 6, Nr. 1, 04.2013, s. 143-159.

Colapietro, V. (1989) Peirce's Approach to the Self: A Semiotic Perspective on Human Subjectivity, Albany, NY: SUNY Press.

Corrington, R. (1993). An Introduction in C.S. Peirce: Philosopher, Semiotician, and Ecstatic Naturalist, Lanham, MD: Rowman \& Littlefield.

Deledalle, G. (2000) Charles Peirce's Philosophy of Signs: Essays in Comparative Semiotics, Bloomington: Indiana University Press.

Dodig-Crnkovic G. and Müller V. (2013), A Dialogue Concerning Two World Systems: InfoComputational vs. Mechanistic. Book chapter in: Information and Computation, World Scientific Publishing Co. Series in Information Studies. Editors: G Dodig-Crnkovic and M Burgin, 2013 Eigen, M., et al. (1981): “The Origin of Genetic Information”, Scientific American, April, pp. 78-94. Engels F. (1873-1886). Dialectics of Nature. Translated by J. B. S. Haldane, 1939. International Publishers Co (April 1968)

Esposito, J. L. (1980). Evolutionary Metaphysics: The Development of Peirce's Theory f the Categories, Athens, Ohio: Ohio University Press.

Favareau, D. (Ed.) (2010). Essential Readings in Biosemiotics: Antology and Commentatry. Berlin and New York: Springer.

Fisch, M.H. (1986) Peirce, Semeiotic, and Pragmatism, edited by K.L Ketner and C Kloesel (eds.), Bloomington: Indiana University Press.

Hoffmeyer, J. and Emmeche C. (1991): "Code-duality and the semiotics of nature". In Anderson, Myrdene and Floyd Merrell, eds. On Semiotic Modeling. Berlin: Mouton de Gruyter, 117-166. Hoffmeyer, J., (1998): On the Origin of Intentional Systems. In Gerald F. Carr Wayne Herbert, \& Hookway, C. (1992): Peirce, London and New York: Routledge.

Kuhn, T. (1962). The Structure of Scientific Revolutions. Chicago: University of Chicago Press. Kull, K., Deacon, T. Emmeche, C., Hoffmeyer, J. and Stjernfelt, F. (2009). Theses on Biosemiotics: Prolegomena to a Theoretical Biology, Biological Theory 4(2) 2009, 167-173.

Küppers, B.-O. (1990): Information and the origin of Life, Cambridge, London: The MIT Press. Liszka, J. J. (1996). A General Introduction to the Semeiotic of Charles Sanders Peirce, Bloomington: Indiana University Press. 
Lorenz, K. (1970-71). Studies in animal and human behaviour I and II, Cambridge: Harvard University Press. Luhmann, N. (1990): Essays on Self-Reference, New York: Colombia University Press. Luhmann, N. (1995): Social Systems. Stanford, CA: Stanford University Press Maturana, H \& Varela, F. (1980). Autopoiesis and Cognition: The realization of the Living, London: Reidel.

Maturana, H \& Varela, F. (1986): Tree of knowledge: Biological Roots of Human Understanding, Shambhala Publishers. London.

Maturana, H.R. (1988a): "Ontology of observing: The Biological Foundation of Self Consciousness and the Physical Domain of Existence" The Irish Journal of Psychology, Vol. 9, no. 1, pp. 25-82. Maturana, H. (1988b): "Reality: The Search for Objectivity, or the Quest for a Compelling Argument" Irish Journal of Psychology, Vol. 9, 1, pp. 25-82.

Menand, L. (2001). The Metaphysical Club: A Story of Ideas in America, New York: Farrar, Strauss and Giroux.

Monod, J. (1972): Chance and Necessity: an essay on the natural philosophy of modern biology, New York: Vintage Books._Murphey, M. G. (1961). The Development of Peirce's Philosophy, Cambridge, MA: Harvard University Press.

Nöth, W. (2012). Charles S. Peirce's Theory of Information: A Theory of the Growth of Symbols and of Knowledge, Cybernetics and Human Knowing, 19 (1-2), 137-161.

Peirce, C.S. (1885), "One, Two, Three: Fundamental Categories of Thought and of Nature", Manuscript 901; the Collected Papers, vol. 1, paragraphs 369-372 and 376-378 parts; the Chronological Edition, vol. 5, 242-247.

Peirce, C. S. (1998). The Essential Peirce. Selected philosophical writings, Vol. 2 (The Peirce Edition Project, Eds.). Bloomington, IN: Indiana University Press.

Peirce, C.S. [ 1931-1935] 1994a): The Collected Papers of Charles Sanders Peirce. Intelex CD-ROM edition (), reproducing Vols. I-VI, Hartshorne, C. and Weiss, P., Eds.; Harvard University Press: Cambridge, MA, USA, 1931-1935; Vols. VII-VIII, Burks, A.W., Ed.; same publisher, 1958. Citations give volume and paragraph number, separated by a period.

Peirce, C.S. (1982-2014). The Writings of Charles S. Peirce: A Chronological Edition. Volumes 1-6 and 8. Eds. Peirce Edition Project, Bloomington: Indiana University Press.

Peirce, C.S. (1994 [1866-1913](1994b): The Collected Papers of Charles Sanders Peirce. Electronic edition reproducing Vols. I-VI ed. Charles Hartshorne \& Paul Weiss (Cambridge: Harvard University Press, 1931-1935), Vols. VII-VIII ed. Arthur W. Burks (same publisher, 1958). Charlottesville: Intelex Corporation. Standard reference is CP X.yyy, where CP is an abbreviation of Collected Papers, X is the volume number and yyy is the paragraph number.

Popper, K. R. (1959). The Logic of Scientific Discovery, London and New York: Routledge. https://archive.org/details/PopperLogicScientificDiscovery

Popper, K. R. (1972). Objective Knowledge: An Evolutionary Approach, Oxford: Oxford University Press.

Prigogine, I. (1980): From Being to Becoming, San Francisco: W.H. Freeman. 
Prigogine, I. (1996): The End of Certainty: Time, Chaos, and the New Laws of Nature. New York: The Free Press.

Prigogine, I. and Stengers, I. (1984). Order Out of Chaos: Man's New Dialogue with Nature, New York: Bantam Books.

Qvortrup. L. (1993). The Controversy over the Concept of Information: An Overview and a Selected and Annotated Bibliography. Cybernetics \& Human Knowing, vol. 1, no. 4: 3-10.

Raposa, M. (1989): Peirce's Philosophy of Religion, Peirce Studies number 5, Bloomington and Indianapolis: Indiana University Press.

Savan, D. (1987-1988), An Introduction to C.S. Peirce's System of Semeiotic, Toronto: Toronto Semiotic Circle.

Shannon, C. (1949). A Mathematic Theory of Communication. In Shannon, C. E. and Weaver, W. (1949). The Mathematical Theory of Communication. Urbana, IL: University of Illinois Press, 1949.

Short, T.L. (2007): Peirce's Theory of Signs, Cambridge: Cambridge University Press.

Smolin, L. (2014). Time Reborn: From the Crisis of physics to the Future of the Universe, London: Allan Lane.

Stjernfelt, F. (2014). Natural Propositions: The account of Peirce's Doctrine of Decisigns, Boston MA: Decent Press.

Weaver, W. (1949). Recent Contributions to The Mathematical Theory of Communication. In Shannon, C. E. and Weaver, W. (1949). The Mathematical Theory of Communication. Urbana, IL: University of Illinois Press .

Whitehead, A. N. (1978), Process and Reality: An Essay in Cosmology, New York: The Free Press. Wiener, N. (1963). Cybernetics; Or, Control and Communication in the Animal and the Machine, Cambridge MA: M.I.T. Press, 1963 